\title{
Microemulsion Copolymerization of Methyl Methacylate and 2-Ethyl Hexylacrylate as a Binder in Leather Finishing
}

Ola A. Mohamed, N. H. Elsayed, A. A. Haroun, Rasha Z. Attia and A. M. Rabie*

${ }^{I}$ Chemistry of Tanning Materials and Leather Technology Department, National Research Center, Dokki, Giza, 12622, and ${ }^{*}$ Chemistry Department, Ain Shams University, Cairo, Egypt.

\begin{abstract}
IN ORDER to minimize the environmental impact in leather 1 industry, water-based recipes are proposed in leather finishing. The application of an acrylic emulsion as a top coat system provides an excellent balance of safety, performance and commerciality in comparison with other coats. An acrylic resin nano-size latex whose colloidal particle size is about $23 \mathrm{~nm}$ with solids content of about $25 \%$ is prepared by copolymerization of methyl methacrylate and 2-ethyl hexylacrylate at different monomer ratios via microemulsion polymerization technique using $\mathrm{K}_{2} \mathrm{~S}_{2} \mathrm{O}_{8}$ as an initiator, $\mathrm{NaHCO}_{3}$ as a buffer and sodium dodecyl sulfate as an emulsifier, performed at $70^{\circ} \mathrm{C}$ for $4 \mathrm{hr}$. The influences of the prepared conditions on the kinetics of emulsion polymerization are studied. The produced copolymers are applied onto leather surfaces of about $90 \mathrm{~mm}$ thick as measured by Elcometer thickness gau ge. The particle size of the latex is tested using dynamic light scattering (DLS), and the composition of the copolymer is analyzed by nuclear magnetic resonance $\left({ }^{1} \mathrm{HNMR}\right)$ and Fourier transform infrared spectroscopy (FTIR). The thermal stability and grain surface fibers texture are examined by thermal gravimetric analysis (TGA) and scanning electron microscope (SEM). Finally, the physical and mechanical properties of uncoated- and copolymercoated leather are studied in details.
\end{abstract}

Keywords: Microemulsion Copolymerization, Binder, Leather Finishing.

Leather is made from a natural hide or skin and becomes flexible, stable material after tanning, retanning, dyeing, fatliquoring and finishing. Finishing is one of the most important processes in the leather production stages. It grants the leather specific characteristics such as colour, feeling, handle, gloss, fastness and durability. The final application of the leathers are wide and include uppers shoe, furniture and automotive upholstery, garments and leather goods, it is for finishing in the best way. The range of chemical products used in finishing is considerable in the final form of leathers, and combinations of these products can produce almost many effects or properties ${ }^{(1,2)}$. 
Finishing products can be classified into pigments, dyestuffs, binders, lacquers or tops and auxiliaries. Binders are products capable of forming a film by drying on the surface of the leather and represent the basic element in a leather finishing formulation. Acrylic resin was successfully used in the leather finishing, where acrylic binders represent the most widely used polymer group for leather finishing and can be used in all stages of finishing that from impregnation to top coats. They generally provide a finish film with a series of excellent properties such as good flexibility, strong adhesion, light fastness, transparent, soft and elastic films and better fastness properties ${ }^{(3-8)}$.

In recent years, microemulsion copolymerization has been subject of many research works and attracts a lot of interest. It is an ultimate polymerization method and widely used in the field of nano-sized material, functional microballoons and drug carriers ${ }^{(9-13)}$.

So far, nano-coatings of the acrylic resin have been widely used in leather finishing. Nano-size colloidal particles are very small and can penetrate into the leather ${ }^{(14)}$. The nano particles have outer carboxyl groups, this can be crosslinked with the collagen that is several tens of nanometers distant and enhance the extension of the leather ${ }^{(3)}$.

The aim of this work is to synthesize microemulsion copolymerization of the methyl methacrylate (MMA) and 2-ethyl hexylacrylate (2-EHA) with different molar ratios to apply on leather surfaces, and then determine the coated and uncoated leather, visually, physically, mechanically and thermally .

\section{Experimental}

\section{Materials}

Crust bovine leather was supplied by Hafez-Abaas Medium Tannery (MisrElkadima, Cairo, Egypt). Methyl methacrylate (MMA) and 2-ethyl hexylacrylate (2-EHA) were provided by Aldrich (Germany) and redistilled before use; potassium persulfate was supplied by Modern Laboratory Co. Sodium bicarbonate was supplied by Fine-Chem Ltd. Sodium dodecyl sulfate was obtained from Merck-Schuchardt Germany.

\section{Methods}

Emulsion polymerization

Microemulsion polymerization was carried out in a 250-ml three-necked flask with a reflux condenser: water, the emulsifier (sodium dodecyl sulfate) (SDS), sodium bicarbonate $\left(\mathrm{NaHCO}_{3}\right)$ and the monomer (metheyl methacrylate \& 2ethyel hexayel acrylate) (MMA\& 2-EHA) were added. Finally, the initiator (potassium persulfate,) (KPS) was dissolved in a small amount of water and added to the reactor under a nitrogen atmosphere. The reactions were run with mechanical stirrer at $800 \mathrm{rpm}$ for $4 \mathrm{hr}$ at $70^{\circ} \mathrm{C}$.

Egypt. J. Chem. 59, No. 5 (2016) 


\section{Monomer conversion determination}

Samples of the reaction mixture were taken at various time intervals. These samples were relatively small so that the overall composition in the reaction vessel was not seriously affected. Once a sample was removed then precipitated in methanol and put in a watch glass. The content of the watch glass was evaporated at room temperature then dried in an electric oven at $60-80^{\circ} \mathrm{C}$ till constant weight. Monomer conversion (MC) was determined by gravimetric analysis method from: MC $\%=\left(\mathrm{m}_{1} / \mathrm{m}_{0}\right)$ X 100

where $\mathrm{m}_{0}$ is the original weight of monomer presents in the sample volume, $\mathrm{m}_{1}$ the weight of dry sample of latex (polymer).

\section{Determination of solid content}

A weighting bottle was placed into the oven (SHEL LAB, 1350 FX Sheldon Manufacuring, Inc.) at $100 \pm 2{ }^{\circ} \mathrm{C}$ for one hr. Next it was put into a desiccator to cool for $30 \mathrm{~min}$. and then weighed. It was again allowed to dry in the oven for one hour and cool until a constant weight was obtained.

Weighing bottle filled with exactly $5.000 \mathrm{~g}$ acrylic resin copolymers were placed into oven at $100 \pm 2{ }^{\circ} \mathrm{C}$ for $6 \mathrm{hr}$ and the same procedure as outlined above was followed.

$$
\text { Solid content }=\left[m_{l}-m_{0}\right] / m \times 100 \%
$$

$m_{l}$ : sample mass after constant weightiness (including weighing bottle mass); $m_{0}$ : weighing bottle mass after constant weight; $m$ : sample mass.

\section{Coating process}

The leather coating proceeds by using Elcometer 3620 Baker film applicator made in Belgium. Every leather piece was coated 3 times by prepared polymers with film thickness $90 \mu \mathrm{m}$ and left to dry.

Nuclear magnetic resonance

${ }^{1} \mathrm{H}$ Nuclear magnetic resonance (NMR) spectra were recorded on a Bruker DRX $500 \mathrm{NMR}$ spectrometer (Bruker, Germany) usually in deuterated $\left(\mathrm{CDCl}_{3}-\mathrm{d}\right)$. The solvent $\left(\mathrm{CDCl}_{3}-\mathrm{d}\right)\left[\delta\left({ }^{1} \mathrm{H}\right)=7.20 \mathrm{ppm}\right.$, was used as internal standard.

Dynamic light scattering (DLS)

The particle size distribution was measured by dynamic light scattering (DLS, Zetasizer Nano ZS, Malvern Instr., UK) in accordance with ISO 22412. Average particles diameters and particle size distribution were determined from the intensityweighted size distributions.

Fourier transform infrared spectroscopy (FT-IR)

FTIR spectra were taken with a Nexus 670 FT-IR spectroscopy (Nicolet, United States) over the range of $400-4000 \mathrm{~cm}^{-1}$ with a resolution of $4 \mathrm{~cm}^{-1}$; the $\mathrm{KBr}$ disk technique was applied. 
Scanning electron microscopy (SEM)

The leather samples $\left(1 \mathrm{~cm}^{2}\right)$ were subjected to sputter coating with gold ions which acted as a conducting medium during scanning, and observed using a Philips Quantan 250 electron microscope.

Thermal gravimetric analysis (TGA)

Thermal analysis was studied with a Perkin Elmer thermogravimetric analyzer $\left(\right.$ rate $=10^{\circ} \mathrm{C} / \mathrm{min}$ ) from room temperature to $600^{\circ} \mathrm{C}$ at the National Research Center of Egypt.

\section{Determination of water absorption}

The test for the determination of the water absorption capacity was based on the immersion of disk specimens with a diameter of $2.5 \mathrm{~cm}$ into water for different time intervals ( $15 \mathrm{~min}, 30 \mathrm{~min}, 60 \mathrm{~min}, 90 \mathrm{~min}, 120 \mathrm{~min}, 150 \mathrm{~min}$ ) at room temperature. The immersed samples were removed from water and excess water was wiped off with filter paper and then weighed.

The water absorption capacity $(\omega)$ was determined with the following relationship:

$$
\omega(\%)=\left(\mathrm{W}-\mathrm{W}_{0}\right) / \mathrm{W}_{0} \times 100
$$

where $\mathrm{W}$ is the weight of wet coated leather after immersion in $\mathrm{H}_{2} \mathrm{O}$ andW $\mathrm{W}_{0}$ is the weight of dry coated leather.

Water vapor permeability

Circle-shaped specimens with a diameter of $6 \mathrm{~cm}$ were used for the measurement of the water vapor permeability. It was carried out with a Herfeld instrument for $72 \mathrm{hr}$ according to standard method 122/2002 (last updated in August 2005) for physical tests of leather from the Egyptian Organization for Standardization and Quality.

\section{Mechanical properties}

Dumbbell shaped specimens $(5 \times 1 \mathrm{~cm}$ with a $4-\mathrm{mm}$-wide neck) were used for the measurement of the tensile strength and elongation at break (\%).These tests were carried out using a Zwick/ Roell (Z010). The test was carried out according to ASTM D 412.

\section{Results and Discussion}

Preparation of Methyl methacrylate/2-Ethyl hexylacrylate copolymer by microemulsion polymerization

The polymerizations of MMA and 2-EHA and their copolymerization were carried out with $\mathrm{K}_{2} \mathrm{~S}_{2} \mathrm{O}_{8}$ (KPS) $(0.2 \mathrm{~g})$ as an initiator, $\mathrm{NaHCO}_{3}(0.25 \mathrm{~g})$ as a buffer and sodium dodecyl sulfate (SDS) $(0.35 \mathrm{~g})$ as an emulsifier at $70^{\circ} \mathrm{c}$ for $4 \mathrm{hr}$ in $100 \mathrm{ml}$ of water.

Egypt. J. Chem. 59, No. 5 (2016) 
Characterization of the prepared polymers

The influences of the prepared conditions such as amount of monomer, monomer mole ratio, surfactant and initiator concentrations on the kinetics of emulsion polymerization were studied in Tables 1-5.

Effect of change of monomers mole ratio of prepared latexes on conversion $\%$ and average particle size

The monomer mole ratio varied between methyl methacrylate (MMA) and 2ethyl hexylacrylate (2-EHA) from 4:1 to $1: 4$ at constant monomer amounts, surfactant concentrations and initiator ratio and the result obtained was presented in Table 1.

TABLE 1. Effect of change of monomer mole ratio of prepared latexes on conversion $\%$ and average particle size .

\begin{tabular}{|c|c|c|c|}
\hline Monomer mole ratio & $\begin{array}{c}\text { Monomer* } \\
\text { \% }\end{array}$ & $\begin{array}{c}\text { Conversion } \\
\text { \% }\end{array}$ & $\begin{array}{c}\text { Av. Particle size } \\
\text { (nm) }\end{array}$ \\
\hline $4: 1$ & 25 & 95.60 & 100.0 \\
\hline $3: 1$ & 25 & 96.60 & 68.00 \\
\hline $2: 1$ & 25 & 96.33 & 58.00 \\
\hline $1: 1$ & 25 & 93.72 & 68.00 \\
\hline $1: 2$ & 25 & 92.98 & 64.00 \\
\hline $1: 3$ & 25 & 89.67 & 63.00 \\
\hline $1: 4$ & 25 & 96.60 & 90.0 \\
\hline
\end{tabular}

*Monomer : MMA+2-EHA $\left(\mathrm{W}_{\mathrm{MMA}} / \mathrm{W}_{2-\mathrm{EHA}}=1\right)$, n-octanol $=1.5 \%, \mathrm{NaHCO}_{3}=0.2 \%, \mathrm{KPS}=0.25 \%$,

SDS $=0.35 \%$, water $=72.70 \%$

For studying the effect of monomer mole ratio concentration on conversion of emulsion polymerization, samples were taken from the reaction mixtures at $4 \mathrm{hr}$ at $70^{\circ} \mathrm{c}$ precipitated in methanol at room temperature, then dried in an electric oven until a constant weight was obtained. When the monomer mole ratio concentration was 2:1, the particle size decreased reaching $58 \mathrm{~nm}$. According to the experimental results of application on the leather surface 2:1 (MMA: 2-EHA) of monomer mole ratio is recommended.

Effect of change of monomer concentrations of prepared latexes on conversion $\%$ and average particle size

The monomer amounts ratio in the feed between methyl methacrylate (MMA) and 2-ethyl hexylacrylate (2-EHA) varied from $15 \%$ to $35 \%$ at constant monomer mole ratio, surfactant concentration and initiator ratio. The results obtained were presented in Table 2.

When the solids content of the acrylic latex increases micelle concentration and collision possibility increase therefore the latex particles' diameters increase. $25 \%$ solid content was the minimum particle size so it used to be comparable with industrial latex in the tannery. 
TABLE 2. Effect of change of monomer amounts of prepared latexes on conversion $\%$ and average particle size .

\begin{tabular}{|c|c|c|c|c|}
\hline $\begin{array}{c}\text { Monomer* } \\
\text { mole ratio }\end{array}$ & $\begin{array}{c}\text { Monomer* } \\
\boldsymbol{\%}\end{array}$ & $\begin{array}{c}\text { Water } \\
\boldsymbol{\%}\end{array}$ & $\begin{array}{c}\text { Conversion } \\
\boldsymbol{\%}\end{array}$ & $\begin{array}{c}\text { Av. Particle size } \\
\text { (nm) }\end{array}$ \\
\hline $2: 1$ & 15 & 82.7 & 95.5 & 37.84 \\
\hline $2: 1$ & 20 & 77.7 & 96.4 & 43.80 \\
\hline $2: 1$ & 25 & 72.7 & 96.5 & 58.00 \\
\hline $2: 1$ & 30 & 67.7 & 96.3 & 68.34 \\
\hline $2: 1$ & 35 & 62.7 & 96.7 & 70.23 \\
\hline
\end{tabular}

*Monomer : $\mathrm{MMA}+2$-EHA $\left(\mathrm{W}_{\mathrm{MMA}} / \mathrm{W}_{2-\mathrm{EHA}}=1\right)$, n-octanol $=1.5 \%$,

$\mathrm{NaHCO}_{3} \%=0.2 \%, \mathrm{SDS}=0.35 \%, \mathrm{KPS}=0.25 \%$

Effect of change of initiator concentrations of prepared copolymer latex on conversion \% and average particle size

Initiator concentration varied between $0.1 \%$ and $0.3 \%$ at constant monomer mole ratio, monomer and surfactant concentrations and the obtained results were presented in Table 3.

TABLE 3. Effect of change of initiator concentrations of prepared latexes on conversion $\%$ and average particle size.

\begin{tabular}{|c|c|c|c|c|c|}
\hline $\begin{array}{c}\text { Monomer* } \\
\text { mole ratio }\end{array}$ & $\begin{array}{c}\text { Monomer* } \\
\text { \% }\end{array}$ & $\begin{array}{c}\text { KPS } \\
\mathbf{\%}\end{array}$ & $\begin{array}{c}\text { Water } \\
\text { \% }\end{array}$ & $\begin{array}{c}\text { Conversion } \\
\text { \% }\end{array}$ & $\begin{array}{c}\text { Av. Particle size } \\
\text { (nm) }\end{array}$ \\
\hline $2: 1$ & 25 & 0.10 & 73.05 & 95.6 & 61.65 \\
\hline $2: 1$ & 25 & 0.15 & 73.00 & 94.8 & 59.20 \\
\hline $2: 1$ & 25 & 0.20 & 72.95 & 97.6 & 58.48 \\
\hline $2: 1$ & 25 & 0.25 & 72.90 & 98.2 & 58.00 \\
\hline $2: 1$ & 25 & 0.30 & 72.85 & 98.4 & 57.70 \\
\hline
\end{tabular}

*Monomer : MMA+2-EHA $\left(\mathrm{W}_{\mathrm{MMA}} / \mathrm{W}_{2-\mathrm{EHA}}=1\right)$, n-octanol=1.5 \%, $\mathrm{NaHCO}_{3}=0.2 \%, \mathrm{SDS}=0.35 \%$.

From Table 3 it can dedetected that the active centers of the reaction increase and the nucleation rate is augmented at initiator concentration increases. Thus the number of colloidal particles also increases and the diameters of particles reduce. Very little reduction of particle diameter was observed when the initiator concentration was above $0.25 \%$. Hence $0.25 \%$ of initiator is recommended.

Effect of change in surfactant concentrations of prepared latexes on conversion $\%$ and average particle size

The surfactant concentration was varied between $0.35 \%$ and $3 \%$ at constant monomer mole ratio, monomer concentration and initiator ratio and the obtained results were presented in Table 4 .

According to Table 4, the colloidal particle size reduced when the concentration of SDS as emulsifier was increased which may be an increase in the number of initial micelles with increased concentration of SDS results in an increased number of colloidal particles and decreased colloidal particle size. Little difference was observed when the concentration of SDS was above $2 \%$. 
TABLE 4. Effect of change of surfactant concentrations of prepared latexes on conversion $\%$ and average particle size.

\begin{tabular}{|c|c|c|c|c|c|}
\hline $\begin{array}{c}\text { Monomer } \\
* \\
\text { mole ratio }\end{array}$ & $\begin{array}{c}\text { Monomer* } \\
\text { \% }\end{array}$ & $\begin{array}{c}\text { SDS } \\
\mathbf{\%}\end{array}$ & $\begin{array}{c}\text { Water } \\
\mathbf{\%}\end{array}$ & $\begin{array}{c}\text { Conversio } \\
\mathbf{n} \\
\mathbf{\%}\end{array}$ & $\begin{array}{c}\text { Av. Particle size } \\
(\mathbf{n m})\end{array}$ \\
\hline $2: 1$ & 25 & 0.35 & 72.70 & 96.2 & 58.00 \\
\hline $2: 1$ & 25 & 0.50 & 72.75 & 95.9 & 49.40 \\
\hline $2: 1$ & 25 & 1.00 & 72.25 & 96.8 & 43.20 \\
\hline $2: 1$ & 25 & 2.00 & 71.25 & 97.4 & 23.40 \\
\hline $2: 1$ & 25 & 3.00 & 70.25 & 98.2 & 22.30 \\
\hline
\end{tabular}

*Monomer : MMA+2-EHA ( $\left.\mathrm{W}_{\mathrm{MMA}} / \mathrm{W}_{2-\mathrm{EHA}}=1\right)$, n-octanol $=1.5 \%, \mathrm{NaHCO}_{3} \%=0.2 \%, \mathrm{KPS}=0.25 \%$.

As Fig. 1 shows that the colloidal particle size distribution with $23 \mathrm{~nm}$ became broader with increased dosage of SDS therefore $2 \%$ of surfactant is recommended.

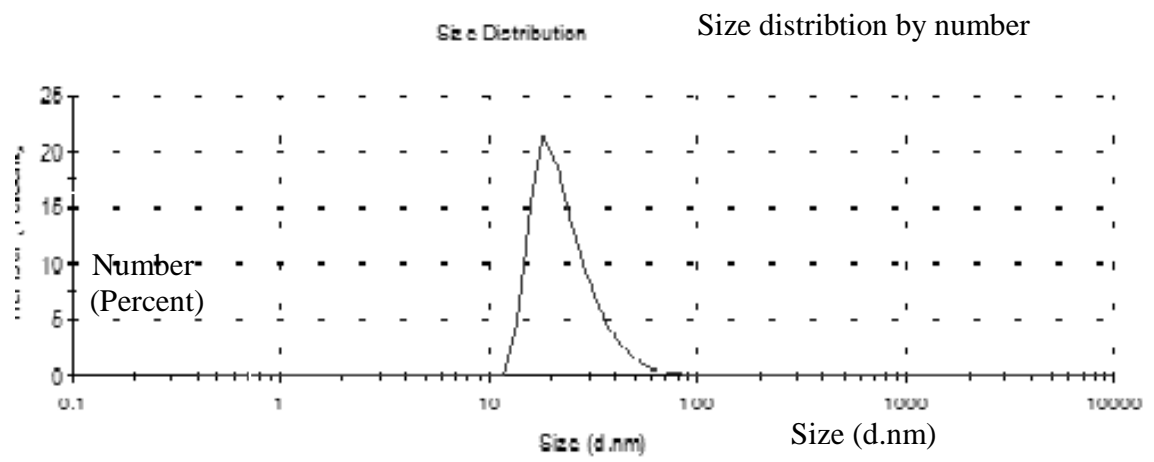

Fig. 1. colloidal particle size of $2 \%$ SDS.

Effect of time on the conversion of monomer emulsion in polymerization

Samples were taken from the reaction mixtures at different time intervals at $70^{\circ} \mathrm{c}$ precipitated in methanol at room temperature, and then dried in an electric oven until a constant weight was obtained. The results are shown in Table 5.

TABLE 5. Effect of time on conversion of emulsion polymerization.

\begin{tabular}{|c|c|c|c|c|c|c|c|c|c|c|c|c|c|}
\hline \multicolumn{10}{|c|}{ Monomer conversion (\%) } \\
\hline $\begin{array}{c}\text { MMA : } \\
\text { 2-EHA } \\
\text { ratio }\end{array}$ & $\begin{array}{c}\text { 30 } \\
\text { Min }\end{array}$ & $\begin{array}{c}\text { 60 } \\
\text { Min }\end{array}$ & $\begin{array}{c}\text { 90 } \\
\text { Min }\end{array}$ & $\begin{array}{c}\text { 120 } \\
\text { Min }\end{array}$ & $\begin{array}{c}\text { 150 } \\
\text { Min }\end{array}$ & $\begin{array}{c}\mathbf{1 8 0} \\
\text { Min }\end{array}$ & $\begin{array}{c}\mathbf{2 1 0} \\
\text { Min }\end{array}$ & $\begin{array}{c}\mathbf{2 4 0} \\
\text { min }\end{array}$ & $\begin{array}{c}\mathbf{2 7 0} \\
\text { Min }\end{array}$ & $\begin{array}{c}\mathbf{3 0 0} \\
\text { min }\end{array}$ & $\begin{array}{c}\mathbf{3 3 0} \\
\text { min }\end{array}$ & $\begin{array}{c}\mathbf{3 6 0} \\
\text { min }\end{array}$ & $\begin{array}{c}\text { Over } \\
\text { night }\end{array}$ \\
\hline $2: 1$ & 15.26 & 86.3 & 87.65 & 88.72 & 88.98 & 89.67 & 93.56 & 96.1 & 96.2 & 96.30 & 96.5 & 97.5 & 99.9 \\
\hline
\end{tabular}

There was an obvious increase in the monomer conversion (\%) with time. After about $240 \mathrm{~min}$, the rate of conversion tended to be steady and this could be attributed to the consumption of monomers with time during the reaction. 
NMR analysis of Methyl Methacrylate and 2-Ethyl Hexylacrylate copolymers

Figure 2 shows the ${ }^{1} \mathrm{H}-\mathrm{NMR}$ spectrum of methyl methacrylate and 2-ethyl hexylacrylate copolymers prepared in emulsion polymerization. The spectrum confirms the assumed structural composition and giving a clean product. In the ${ }^{1} \mathrm{H}-\mathrm{NMR}$ spectrum (Fig. 2) in $\mathrm{CDCl}_{3}$-d it is possible to distinguish protons of Methyl methacrylate units and the free protons in 2-ethyl hexylacrylate furthermore, the acidic protons can be observed.

The ${ }^{1} \mathrm{H}-\mathrm{NMR}$ spectrum of MMA/2-EHA copolymer have the ${ }^{*} \mathrm{CH}_{3}-\mathrm{CH}_{2}$ signals at $0.88 \mathrm{ppm}$, the $\mathrm{CH}_{3}{ }^{*}{ }^{*} \mathrm{CH}_{2}-\mathrm{CH}_{2}$ signals at 1.0-1.27 ppm. In addition, the methylene proton signals the $\mathrm{CH}_{3}-\mathrm{CH}_{2}-* \mathrm{CH}_{2}$ signals overlapping with the $\mathrm{CH}_{3}$ $\mathrm{CH}_{2}-\mathrm{CH}_{2}-* \mathrm{CH}_{2}$ signals and $\mathrm{CH}_{3}-* \mathrm{CH}_{2}-\mathrm{CH}$ between 1.3-1.54 ppm, the $\mathrm{CH}_{2}-* \mathrm{CH}-$ $\left(\mathrm{CH}_{2}\right)_{2}$ overlapped also with the ${ }^{*} \mathrm{CH}_{3-} \mathrm{C}$ signals at $1.88 \mathrm{ppm}$. The signals at 7.2 ppm related to chloroform solvent used, an accurate determination of the structure ratio is impossible from these regions.

However, the methyl signals units of methyl methacrylate $* \mathrm{CH}_{3}-\mathrm{O}$ signals are separated well at $3.4 \mathrm{ppm}$ and methylene proton signals of 2-ethyl hexylacrylate The $\mathrm{O}-{ }^{*} \mathrm{CH}_{2}-\mathrm{CH}$ signals appear at $3.88 \mathrm{ppm}$, our results are in a good agreement with the literature $^{(15)}$. Obviously, $500 \mathrm{MHz}-1 \mathrm{H}$ NMR spectra cannot be used for a complete quantitative structure analysis of our polymers. The signal at $1.88 \mathrm{ppm}$ can be assigned to the proton $\mathrm{H}_{3}$ of the focal group. Since only one focal group per polymer is present and no cyclization has been observed as side reaction.

The absence of the vinyl part $* \mathrm{CH}=\mathrm{CH}_{2}$ signals at $6.2 \mathrm{ppm}$ and $\mathrm{CH}=* \mathrm{CH}_{2}$ signals at 5.8, $6.4 \mathrm{ppm}$ which exist in the 2-ethyl hexylacrylate monomer and the vinyl part $* \mathrm{CH}_{2}=\mathrm{C}$ - signals at 5.5, $6.1 \mathrm{ppm}$ which exist in the methyl methacrylate monomer prove the complete reaction of the emulsion polymer and formation of methyl methacrylate and 2-ethyl hexylacrylate copolymer and also formation of the new $* \mathrm{CH}_{2}-* \mathrm{CH}_{2}-* \mathrm{CH}$ signals which appeared in the region of $1.8-1.9 \mathrm{ppm}$.

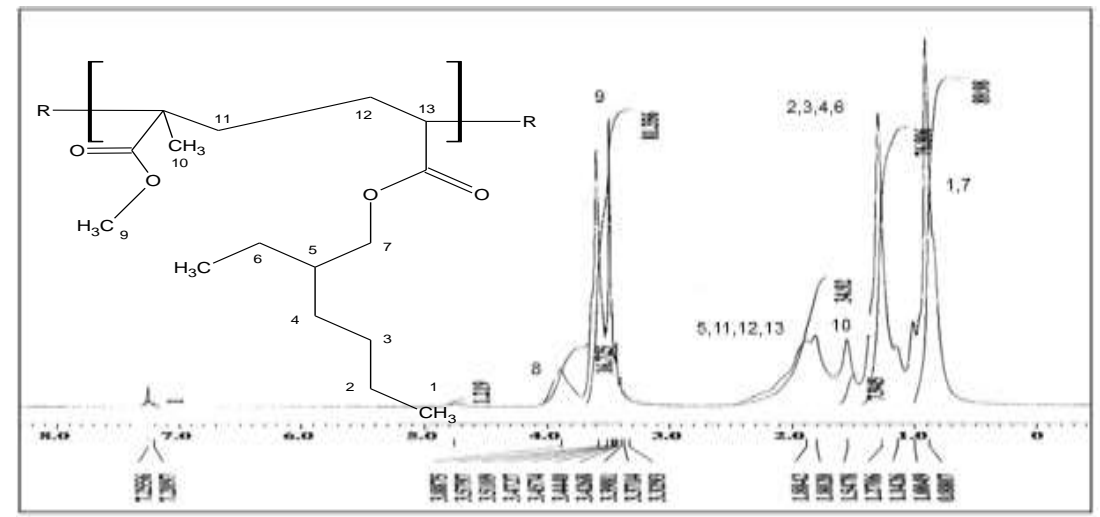

Fig. 2. ${ }^{1}$ H-NMR spectrum of Methyl Methacrylate and 2-Ethyl Hexylacrylate copolymers measured in $\mathrm{CDCl}_{3}$-d.

Egypt. J. Chem. 59, No. 5 (2016) 


\section{FT-IR spectra of the coated leather}

The FT-IR spectrum shows characteristic absorbance peaks of the chemical groups of the leather, methyl methacrylate/2-ethylhexylacrylate copolymer and the leather treated with $(2: 1)$ copolymer samples in Fig.3 and Table 6. The absorbance bands are identified as follows: a strong and a broad overlapping band in the range of $3600-3300 \mathrm{~cm}^{-1}$ was assigned to $\mathrm{NH}$ bond in the peptide group of collagen and protein in the leather and for the $\mathrm{OH}$ of carboxylic group in the leather, the bands at $2951,2872 \mathrm{~cm}^{-1}$ are from $-\mathrm{CH}_{3}$ and $-\mathrm{CH}_{2}$ stretching vibrations for the leather and copolymer chain, the strong band at $1680,1734 \mathrm{~cm}^{-1}$ is due to $\mathrm{C}=\mathrm{O}$ overlapping between carbonyl group of leather and the two carbonyl groups of methyl methacrylate/2-ethylhexylacrylate copolymer stretching vibrations, the bands at $1388 \mathrm{~cm}-1$ and $1457 \mathrm{~cm}^{-1}$ are due to $-\mathrm{CH}_{3}$ and $\mathrm{CH}_{2}$ bending vibration. The band at $1239 \mathrm{~cm}^{-1}$ was assigned to $\mathrm{NH}$ bending vibration of the amide group and the band at $1152 \mathrm{~cm}^{-1}$ is attributed to the strong C-O-C of methyl methacrylate/2-ethylhexylacrylate copolymer stretching vibrations, the bands at $987 \mathrm{~cm}^{-1}, 969 \mathrm{~cm}^{-1}, 695 \mathrm{~cm}^{-1}$ are $-\mathrm{C}-\mathrm{C}-$ of the skeletal stretch and CH out off plane ${ }^{(16-18)}$.

TABLE 6. FT-IR spectra and assignments for leather, MMA/2-EHA (2:1) copolymer and leather treated with MMA/2-EHA (2:1).

\begin{tabular}{|c|c|c|c|c|}
\hline \multirow[b]{2}{*}{ Region } & \multicolumn{3}{|c|}{ Peak wave number $\mathrm{cm}^{-1}$} & \multirow[b]{2}{*}{ Assignment } \\
\hline & Leather & $\begin{array}{l}\text { MMA/2- } \\
\text { EHA }\end{array}$ & $\begin{array}{c}\text { Leather } \\
\text { treated with } \\
\text { MMA/2-EHA }\end{array}$ & \\
\hline \multirow[t]{4}{*}{ Amide A } & 3500 & -------- & 3500 & NH stretch \\
\hline & 3340 & 3440 & 3346 & $\mathrm{OH}$ stretch of water \\
\hline & 2930 & 2951 & 2930 & $\mathrm{CH}_{2}$ asymmetrical stretch \\
\hline & 2850 & 2872 & 2852 & $\mathrm{CH}_{2}$ symmetrical stretch \\
\hline Amide I & 1680 & 1734,1646 & 1670 & $\begin{array}{l}\mathrm{C}=\mathrm{O} \text { stretch coupled with } \\
\text { COO- }\end{array}$ \\
\hline \multirow[t]{3}{*}{ Amide II } & 1552 & --------- & 1548 & $\begin{array}{l}\text { NH bend coupled C-N } \\
\text { stretch }\end{array}$ \\
\hline & 1455 & 1457 & 1453 & $\mathrm{CH}_{2}$ bend \\
\hline & 1338 & 1388 & 1335 & $\begin{array}{c}\mathrm{CH}_{3} \text { bend, } \mathrm{CH}_{2} \text { wagging of } \\
\text { proline }\end{array}$ \\
\hline \multirow[t]{2}{*}{$\begin{array}{l}\text { Amide } \\
\text { III }\end{array}$} & 1230 & 1239 & 1235 & $\mathrm{NH}$ bend \\
\hline & 1046 & 1161 & $1040-1100$ & C-O stretch \\
\hline $\begin{array}{l}\text { Amide } \\
\text { IV }\end{array}$ & 695 & 987 & 969 & Skeletal stretch \\
\hline Amide V & 630 & 844 & 917 & $\begin{array}{l}\text { CH out off plane, skeletal } \\
\text { stretch }\end{array}$ \\
\hline $\begin{array}{l}\text { Amide } \\
\text { VI }\end{array}$ & 593 & 759,629 & $861,674,618$ & $\begin{array}{l}\mathrm{CH} \text { out off plane, skeletal } \\
\text { stretch }\end{array}$ \\
\hline
\end{tabular}

Egypt. J. Chem. 59, No.5 (2016) 


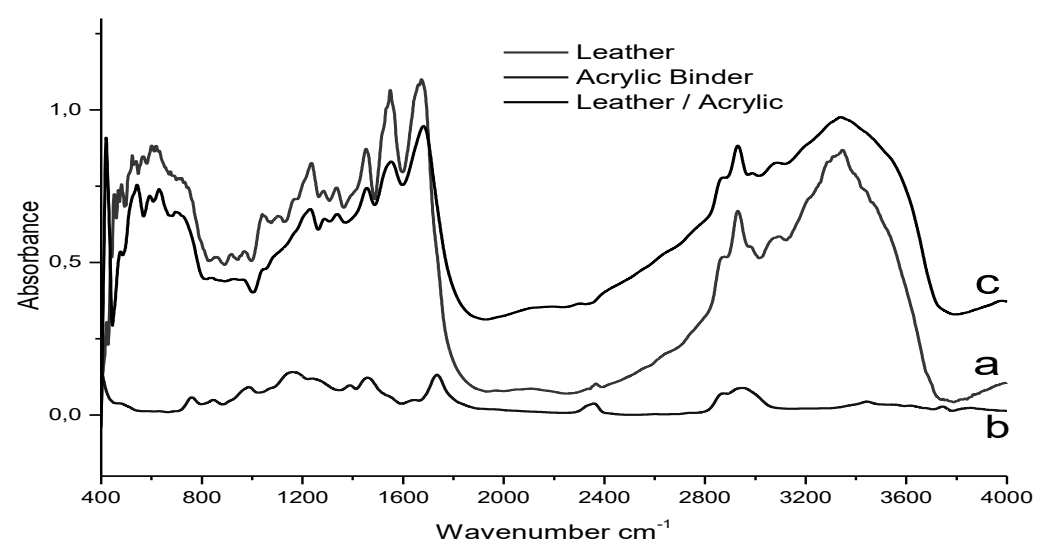

Fig. 3. FT-IR spectra of (a-Leather, b-Methyl methacrylate 2-ethyl hexylacrylate copolymers (2:1), c-Leather treated with MMA/2-EHA (2:1).

Evaluation of the coated leather

Effect of the coating layer on the water absorption content

The effects of copolymerization of methyl methacrylate and 2-ethyl hexylacrylate copolymers and their different mole ratios on the water absorption of the coated leather are shown in Fig. 4. It was noted that; by increasing time of immersion in water for both coated and uncoated leather samples caused an increase in the water absorption percentage. ${ }^{(19,20)}$

All the coated samples had more water resistance than the uncoated one because of the pores of leather is filling through the coating layer with the different polymers, especially those with a higher ratio of methyl methacrylate with its hydrophobic character.

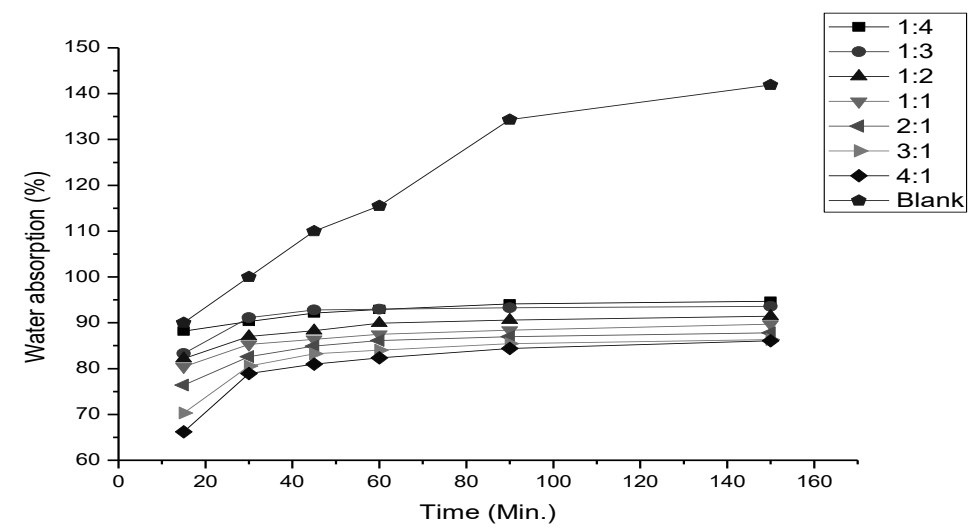

Fig. 4. Effect of the coating layer on the water absorption.

Egypt. J. Chem. 59, No. 5 (2016) 
Water vapor permeability of coated leather

Water vapor permeability of the leather is a combination of the process that water moves through the stomas and water transfers with the hydrophilic groups of collagen under a certain vapor pressure. Water vapor permeability of the leather will be declined after the leather is finished. Table 7 shows that water vapor permeability of the coated leather by different molar ratio of $\mathrm{P}(\mathrm{MMA} / 2-$ EHA) is higher than the uncoated leather .

In case of increasing the percentage of 2-EHA causing the aggregation and supersaturation of coating films of $1: 2$ to $1: 4$, the water vapor permeability of the coated leather increased. 2-EHA increases the hydrophilic groups, which quicken the transmission of $\mathrm{H}_{2} \mathrm{O}$ molecules. In case of increasing the concentration of MMA reaching to P(MMA:2-EHA) (4:1), the water vapor permeability of the coated leather decreased, due to the formation of hydrophobic groups, which render the transmission of $\mathrm{H}_{2} \mathrm{O}$ molecules forming films.

TABLE 7. Effects of different copolymers molar ratio on the water vapor permeability of coated leather.

\begin{tabular}{|c|c|}
\hline $\begin{array}{c}\text { Leather samples coated with different } \\
\text { copolymers molar ratio }\end{array}$ & $\begin{array}{c}\text { Increase rate of water vapor } \\
\text { permeability (\%) }\end{array}$ \\
\hline $\mathrm{P}(\mathrm{MMA} / 2-\mathrm{EHA})(1: 4)$ & 5.1 \\
\hline $\mathrm{P}(\mathrm{MMA} / 2-\mathrm{EHA})(1: 3)$ & 4.4 \\
\hline $\mathrm{P}(\mathrm{MMA} / 2-\mathrm{EHA})(1: 2)$ & 3.2 \\
\hline $\mathrm{P}(\mathrm{MMA} / 2-\mathrm{EHA})(1: 1)$ & 4.3 \\
\hline $\mathrm{P}(\mathrm{MMA} / 2-\mathrm{EHA})(2: 1)$ & 6.0 \\
\hline $\mathrm{P}(\mathrm{MMA} / 2-\mathrm{EHA})(3: 1)$ & 4.0 \\
\hline $\mathrm{P}(\mathrm{MMA} / 2-\mathrm{EHA})(4: 1)$ & 1.0 \\
\hline
\end{tabular}

Scanning electron microscope (SEM)

A morphological study was carried out for untreated leather in comparison with coated leather by copolymers. SEM is thus a useful technique for evaluating the effects of various treatments on the leather and it can be used to assess the penetration of the copolymer through the leather and into the hierarchy of the structure. SEM of the grain surface (x100) and the cross-section of the (x600) of the leather with and without copolymers coating were carried out to show the effect of the prepared copolymers on the grain and fiber bundles as a binder in finishing leather.

Figures 5-14 present SEM images for blank leather and leather coated with P(MMA : 2-EHA) with different molar ratios (1:1); (1:2); (1:3); (1:4); (2:1); (3:1) and (4:1), respectively. 
Figure 5 shows the presence of uncoated grain of crust leather composed of interwoven collagen fibers and hair holes follicles even at low magnification. On the other hand, in the coated leather samples shown in Figures 6-14, the pores filled with the prepared copolymers and this can confirm the coating process.

More investigations were carried out, Fig.6 represent the image of leather coated with P(MMA : 2-EHA) (1:1) where there were still small pores left after the coating process which was observed clearly in high magnification with non uniform and homogeneity copolymer film of P(MMA: 2-EHA) and these pores can give the leather the chance to breath and help in the transfer of water vapor. From Fig. 7 - 9 there were increasing in the percentage of 2-EHA causing the aggregation and supersaturation of coating films of $1: 2$ to $1: 4$. This was the reason of the tackticity and the poor filling and coating of the covered leather, regularity and softness of the coating film increased with increasing 2-EHA content because of the low glass-transition temperature $(\mathrm{Tg})$, which made the formed film softer and more elastic.

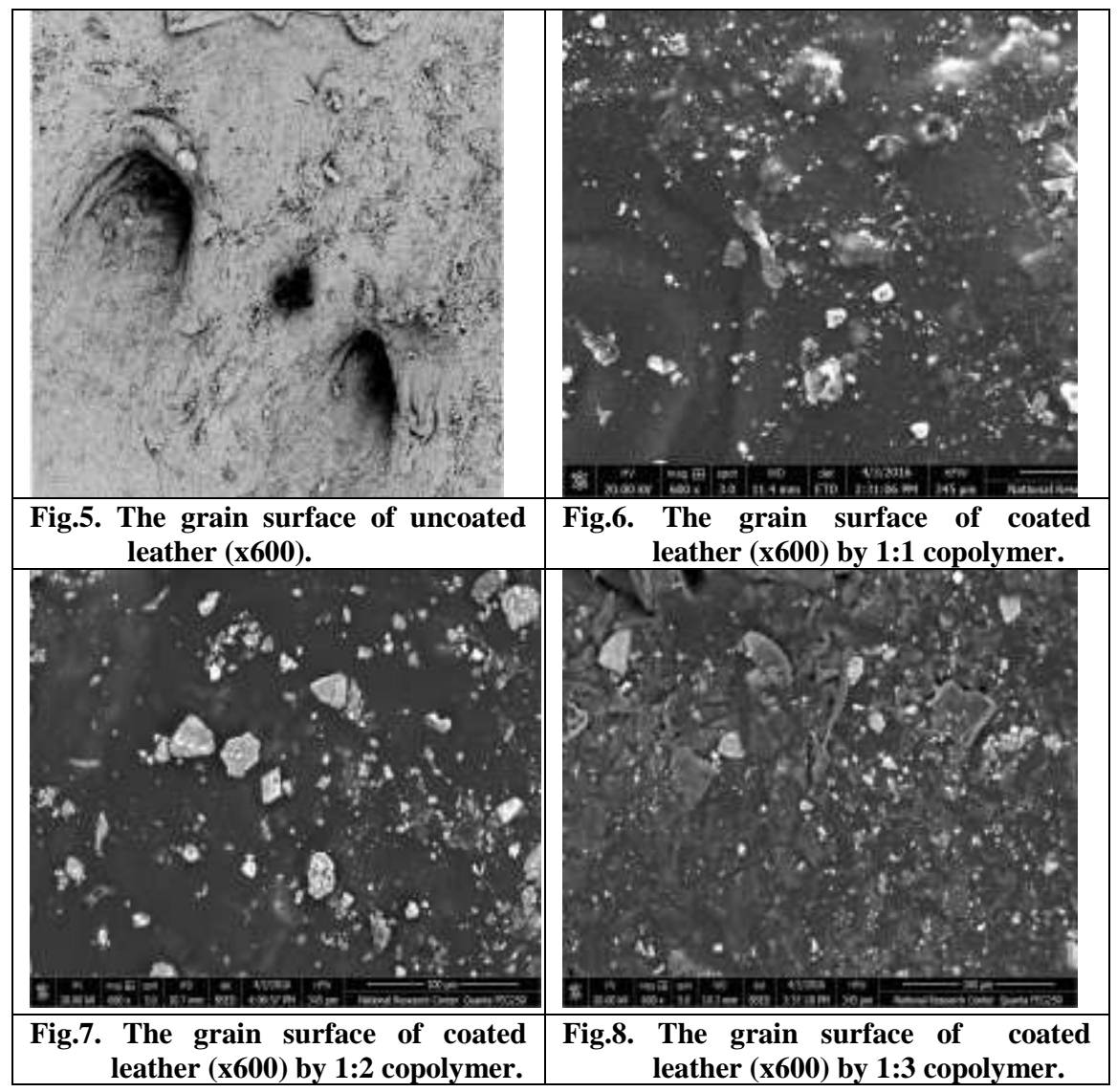

Egypt. J. Chem. 59, No. 5 (2016) 
In case of increasing the amount of MMA reaching P(MMA:2-EHA) (2:1) shown in Fig. 10, leather completely fine covered without any aggregation of the copolymers which was observed clearly in high magnification with uniform and homogeneity of copolymer film, and showed a significant lubrication of fiber bundles, and surface grain is fine. However getting to P(MMA:2-EHA) (3:1) in Fig. 11 the cracks starting to appear in the leather surface reaching to the higher level of cracks a rigid film formed with high concentration of MMA at P(MMA:2-EHA) (4:1) (Fig.12). It was concluded that the SEM of the samples treated by copolymer P(MMA:2-EHA) (2:1) has a smooth soft fiber, firmness grain, filling and modified handle, which are good evidence for the penetration and lubrication of copolymers into the leather fibers and grain surface.

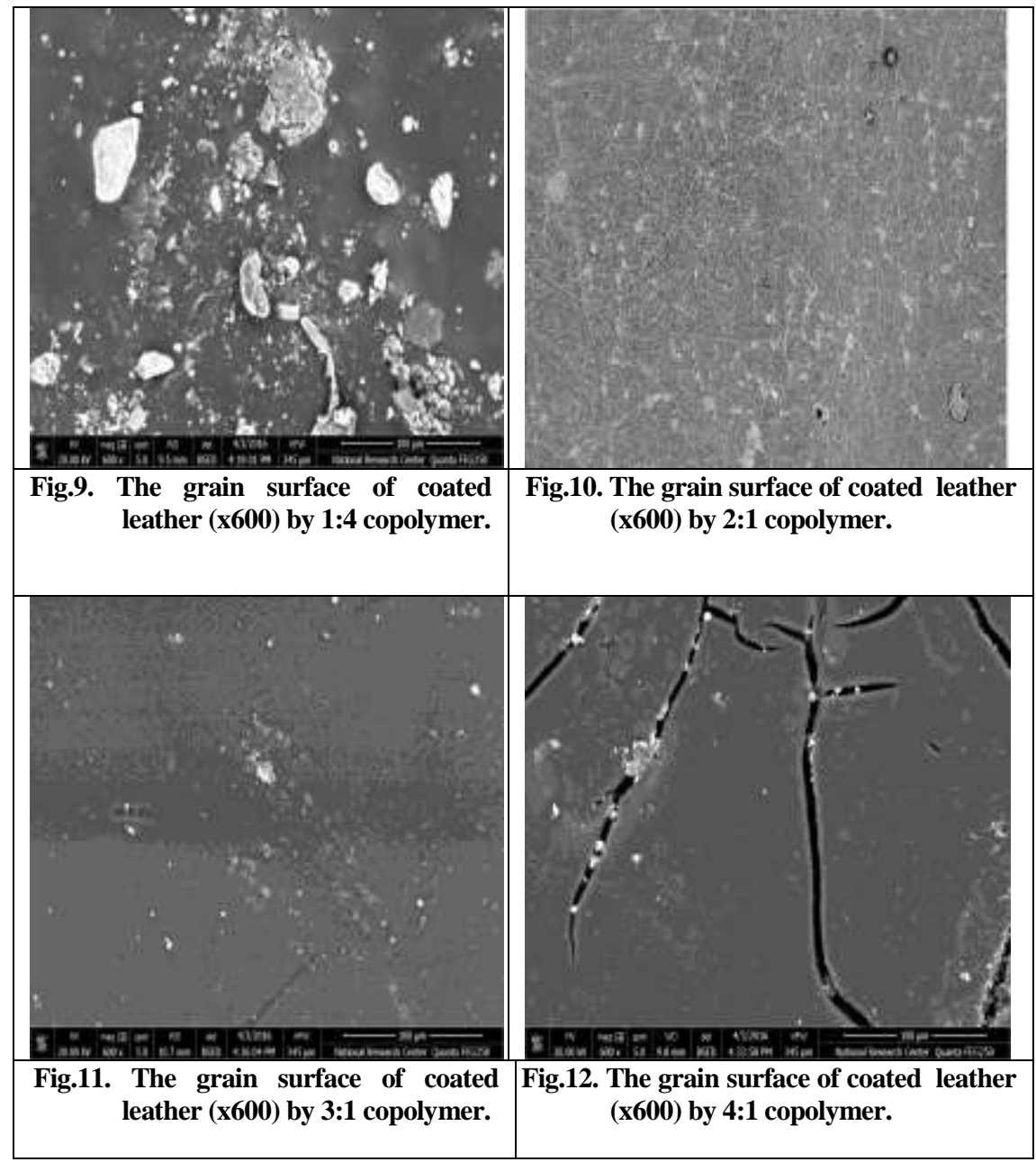

Egypt. J. Chem. 59, No.5 (2016) 


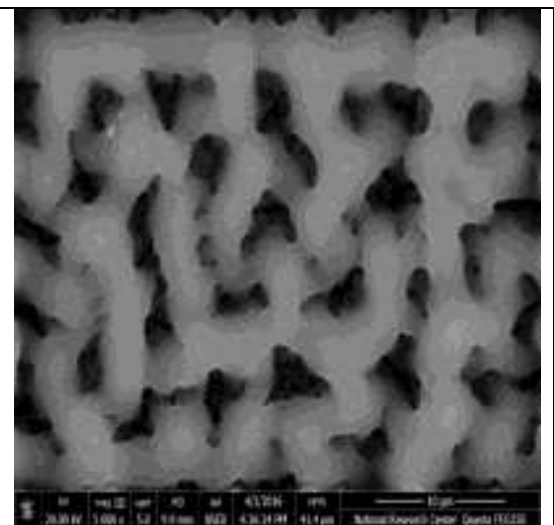

Fig.13. The fiber bundles of coated leather $(x 5000)$ by 4:1 copolymer

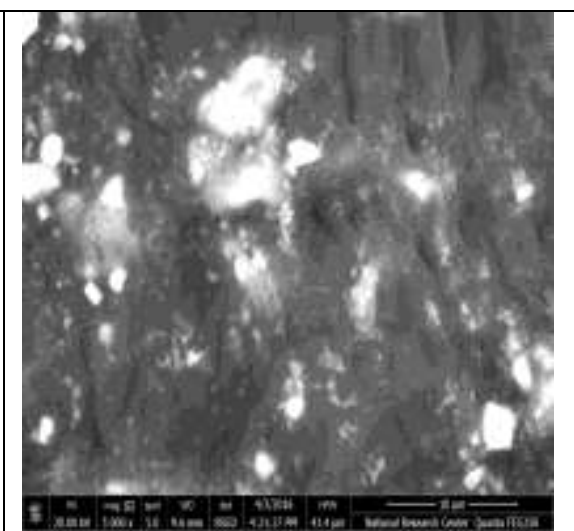

Fig.14. The fiber bundles of coated leather $(\mathbf{x 5 0 0 0 )}$ by $1: 4$ copolymer

\section{Mechanical properties of coated leather}

Relation between the type of leather coating with tensile strength, elongation at break $(\%)$ and tear strength are determined and the results is presented in Table 8 .

TABLE 8. Relation between the molar ratio coating with tensile strength, elongation at break $(\%)$ and tear strength.

\begin{tabular}{|l|c|c|c|}
\hline $\begin{array}{l}\text { Composition of coated } \\
\text { leather samples }\end{array}$ & $\begin{array}{c}\text { Tensile strength } \\
\mathbf{M P a}\end{array}$ & $\begin{array}{c}\text { Elongation at } \\
\text { break } \\
\mathbf{\%}\end{array}$ & $\begin{array}{c}\text { Tear strength } \\
\mathbf{N} / \mathbf{c m}\end{array}$ \\
\hline Blank & 10.4 & 40 & 262.8 \\
\hline P(MMA:2-EHA) $(4: 1)$ & 11.0 & 42 & 317.7 \\
\hline P(MMA:2-EHA) $(3: 1)$ & 11.4 & 50 & 415.8 \\
\hline P(MMA:2-EHA) $(2: 1)$ & 18.7 & 75 & 422.3 \\
\hline P(MMA:2-EHA) $(1: 1)$ & 19.1 & 81 & 433.4 \\
\hline P(MMA:2-EHA) $(1: 2)$ & 19.5 & 83 & 440.6 \\
\hline P(MMA:2-EHA) $(1: 3)$ & 21.7 & 85 & 463.7 \\
\hline P(MMA:2-EHA) $(1: 4)$ & 22.4 & 90 & 492.8 \\
\hline
\end{tabular}

The strengthened fibers properties have been generally given the greatest consideration in the evaluation of leather. The mechanical characters always include the measurement of the tensile strength, tear strength and elongation $\%$ at break. These characters were carried out according to the Egyptian standard method (ES-123) and official methods, and an average value of at least five test samples was taken for each item. Table 8 showed, in general, an improvement in the mechanical properties of treated leather by copolymers than untreated leather, this may be due to the good adhesion effect of the copolymer on the fiber of the leather and also due to the filling of grain layer.

Egypt. J. Chem. 59, No. 5 (2016) 
It is noticeable that coating agents covered the pores of hair follicles hide parts, resulting in more strength for leather fibers. From Table 8, the leather samples coated with higher concentration of MMA had a lower value of tensile strength and tear strength than the other coating samples because of the hard film formed by P(MMA:2-EHA) (4:1) which are in a good agreement with the cracks formed on the surface of the coated leather shown in SEM results (Fig. 13). It was also observed clearly in high magnification that polymers interact completely with the grain of interwoven collagen fibers allow the leather to be more hard with a lot of cracks as shown in Fig. 13 due to a high Tg value of the MMA monomer $\left(105^{\circ} \mathrm{C}\right)$ which would mostly produce a hard and brittle film. The results are in good agreement with what is reported in the literature ${ }^{(3)}$.

However, with increasing 2-EHA content, the tensile strength, elongation at break $\%$ and tear strength of the samples increased and reached the maximum for samples coated with P(MMA:2-EHA) (1:4); this was due to the low Tg value of 2-EHA, which was equal to $-50^{\circ} \mathrm{C}$; this made the film very soft and tackticity will be higher due to the interaction of polymer with interwoven collagen fibers let it more elastic and swollen as shown in higher magnification of leather coated with P(MMA:2-EHA) (1:4) (Fig. 14), it filled the pores well and reinforced the fibers.

\section{Thermal gravimetric analysis (TGA) of coated leather}

Figure 15 shows the TGA curves the decomposition temperature of the copolymer- finished leather is at higher values than that of untreated crust leather. Thus, the incorporation of the copolymer into leather increases the thermal stability of the collagen/copolymer leather over that of the crust or blank leather; this is shown in Fig. 15. This improvement in thermal stability can be attributed to the formation of polymer /collagen composite which can be illustrated by brought about multiple weak hydrogen bonding between the numerous carbonyl groups $(\mathrm{C}=\mathrm{O})$ of the copolymers as shown in NMR results and the countless hydrogen atoms of $(\mathrm{NH})$ peptide groups in the leather, which support the linkages between the polymers and grain of corium in the leather. These results indicate that copolymers filling up and lubricating the interwoven collagen fibers and hair holes follicles of leather fibers.

The thermo-gravimetric curve of crust leather shows two-step degradation, however leather coated with copolymer P(MMA/2-EHA) (2:1) suggests and shows three-step degradation, with an initial weight loss of about $9-11 \%$ at $100^{\circ} \mathrm{C}$ due to the release of moisture and water included in the leather fibers. After this process, the leather fiber was approximately stable up to $291{ }^{\circ} \mathrm{C}$, at which gradual decomposition began to take place.

From Fig.15, it can be observed that at first degradation step at $290-380^{\circ} \mathrm{C}$, there was a loss of nearly $52 \mathrm{wt} \%$ that resulted from the burning of organic hydrocarbon chains of the leather and the evaporation of $\left(\mathrm{CO}, \mathrm{CO}_{2}, \mathrm{CH}\right.$ and $\mathrm{CH}_{2}$ ). The TGA curves for each sample start to differ significantly only above $380^{\circ} \mathrm{C}$. The second decomposition at $413-460^{\circ} \mathrm{C}$ included the degradation of the 
polypeptide polymers side chains and chromium and polymers attached to the protein in the corium layer. The third degradation at $470-500^{\circ} \mathrm{C}$ included the degradation of the backbone of the copolymer.

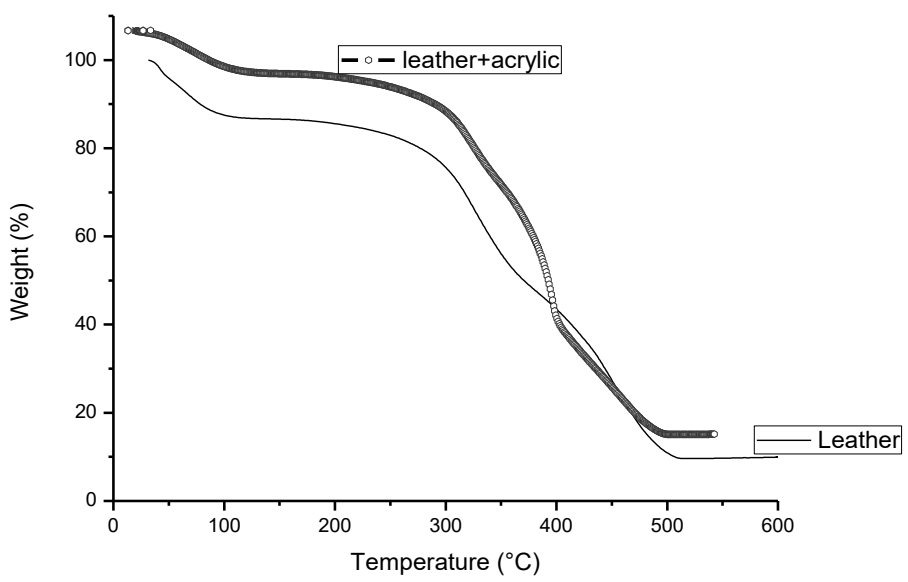

Fig.15. TGA of coated and uncoated leather.

\section{Conclusions}

Acrylic resin nano-size latex whose colloidal particle size was about $23 \mathrm{~nm}$ and solids content about $25 \%$ was prepared by copolymerization of methyl methacrylate and 2-ethyl hexylacrylate by microemulsion polymerization technique with $\mathrm{K}_{2} \mathrm{~S}_{2} \mathrm{O}_{8}, \mathrm{NaHCO}_{3}$ and sodium dodecyl sulfate as the emulsifier at $70^{\circ} \mathrm{C}$ for $4 \mathrm{hr}$.

The physical properties results showed that the water absorption content was high, however decreased with increasing methyl methacrylate content, and the water vapor permeability of the coated leather was better than that of the uncoated leather. The mechanical properties such as the tensile strength increased from 10.4 to $19.5 \mathrm{MPa}$, elongation at break (\%) by $40 \%$ and the tear strength improved from 262.8 to $440.6 \mathrm{~N} / \mathrm{cm}$ after coating with poly(methyl methacrylate and 2-ethyl hexylacrylate) (2:1). IR spectra for coated leather showed new bands characteristic of methyl methacrylate and 2-ethyl hexylacrylate, which have no existence in the spectrum of uncoated leather.

Finally, scanning electron microscopy showed full softer and smooth grain surface in the coated leather with MMA/2-EHA (2:1) with no cracks or supersaturating of copolymer. Thermogravimetric analysis showed characteristic improvements in the thermal stability of leather after the coating; its optimum stability was reached when the leather was coated with poly (methyl methacrylate and 2-ethyl hexylacrylate) (2:1). The study succeeded in preparation of a copolymer in nanosize for leather finishing. 


\section{References}

1. Jing, H., Jianzhong, M. and Weijun D., Synthesis of alkali-soluble copolymer (butyl acrylate/acrylic acid) and its application in leather finishing agent, European Polymer Journal, 44, 2695-2701, (2008).

2. Mohamed, O. A., Moustafa, A. B., Mehawed, M. A. and El-Sayed, N. H., Styrene and butyl methacrylate copolymers and discussed their application in leather finishing. Journal of Applied Polymer Science, 111,1488-1495 (2009).

3. Wang, X., An, H., Sun, M., Luo Y. and Feng Jianyan, An acrylic resin retanning agent with a reinforcing effect: synthesized by high solids content microemulsion copolymerization, Journal of the Society of Leather Technologists and Chemists, 89,164-168 (2004).

4. Bacardit, A., Canals, T., Cobos, M., Shendryck, A., Solé, O. and Ollé, L., Characterization and evaluation of four types of finish topcoats. Journal of the Society of Leather Technologists and Chemists, 93, 130-139, (2009).

5. Bacardit, A., Ollé, L., Morera, J. M., Bartoli, E. and Fernaàndez, D., Cross-linked polymers for aqueous finishing, part II behaviour of acrylic binders. Journal of the Society of Leather Technologists and Chemists, 92, 157-161, (2008).

6. Hoefler, J., Hageman, B., Chung, C.J. and Smith, R., High performance acrylic polymer technology for use in leather finishing processes. JALCA, 108, 311-318, (2013).

7. Yılmaza, O., Cheaburu, C. N., Gülümser, G. and Vasile, C., Rheological behaviour of acrylate/montmorillonite nanocomposite latexes and their application in leather finishing as binders. Progress in Organic Coatings, 70, 52-58, (2011).

8. Abu-Ayana, Y.M. and Mohamed, O.A., Preparation and application of modified urea formaldehyde resin as leather finishing with polyvinyl latex. Egypt .J. Text. Polym. Sci.Technol. 12, 2, 195-207 (2008)

9. Guangxiang, Z., Xiangling, X. and Jianguo, T., Formation of microporous polymeric materials by microemulsion radiation polymerization of butyl acrylate. Journal of Applied Polymer Science, 77 (9), 1989-1993, (2000).

10. Hammond, A., Budd, P. M. and Price, C., Microemulsion polymerization of butyl acrylate and methyl methacrylate. Progress in Colloid \& Polymer Science, 113, 142 149, (1999).

11. Tauer, K., Ramirez, A. G. and Lopez, R. G., Effect of the surfactant concentration on the kinetics of oil in water microemulsion polymerization: a case study with butyl acrylate. Comptes Rendus Chimie, 6 (11-12), 1245-1266, (2003).

12. Bhawal, S., Pokhriyal, N. K. and Devi, S., Translucent nanolatexes through emulsion polymerization of ethyl acrylate. European Polymer Journal, 38, 735-744, (2002). 
13. Donescu, D., Fusulan, L. and Petcu, C., Ternary microemulsions of vinylic and acrylic monomers. European Polymer Journal, 38, 1691-1701 (2002).

14. Xuechuan, W. and Ming S., The distribution of nanometer oxide powder and its application in fatliquoring. West Leather, 26 (4), 31-35 (2004).

15. Zaioncz, S., Silva, A.A., Sirqueira, Alex S. and Soares B.G., Macromol. Mater. Eng. 292, 1263-1270, (2007).

16. Afremow, L. C., Isakson, K. E., Netzel, D. A., Tessari, D. J. and Vandeberg, J. T., Infrared Spectroscopy: Its Use in the Coatings Industry; Federation of Societies for Paint Technology: Philadelphia, p 65 (1969).

17. William, K., Organic Spectroscopy, $2^{\text {nd }}$ ed.; Macmillan Education: Hong Kong, (1982).

18. Pavia, D.N., Lampman, G.M. and Kriz, G.S., Introduction to Spectroscopy; Saunder College: Philadelphia (1979).

19. Amudeswari, S., Reddy, C. R. and Joseph, K. T., Eur. Polym .J, 20, 91-93, (1984).

20. Klasek, A., Kaszonyiova, A. and Pavelka, Journal of Applied Polymer Science, 31, 7, 2007-2019 (1986)

Received 21/6/2016,

Accepted25/7/2016

Egypt. J. Chem. 59, No. 5 (2016) 


\section{البلمرة المستحلبة بطريقه الميكرو لميثاكريليت الميثيل و2-إيثيل اكريليت الهيكسيل وتطبيقها في تثطيب الجلود الجيكي}

علا عبدالتواب عملم ، نبيل حسين السيد، احمد عوض هارون ، رشا زكريا عطية

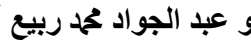

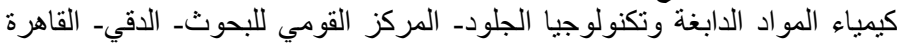

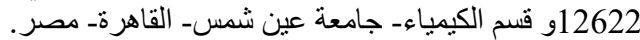

تلقليل التلوث البيئي الناتج من صناعة الجلود يتم استخدام مو اد لشطيب الجلود التىى التي

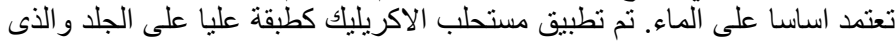

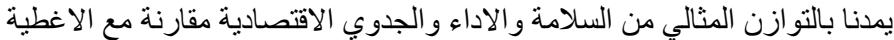

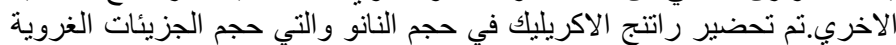

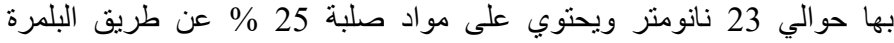

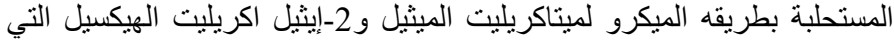

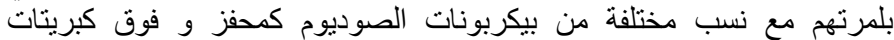

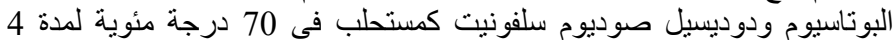

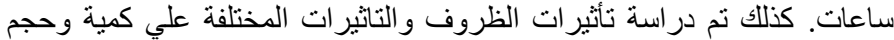

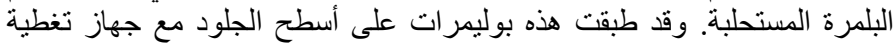

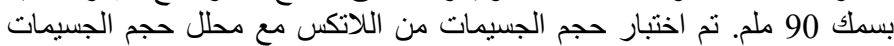

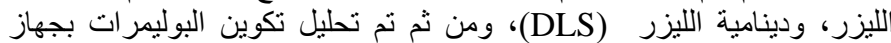

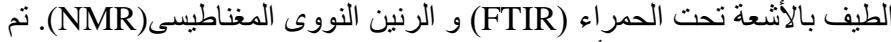

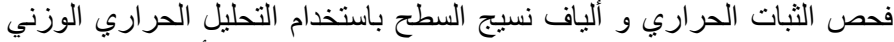

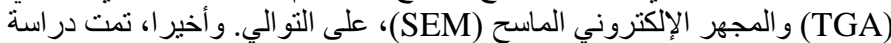

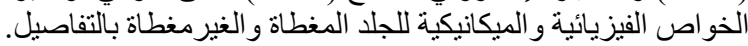

